\title{
Structural Reinterpretation of Poverty by Examining Working Poverty: Implications for Community and Policy Practice
}

\author{
Philip Young P. Hong \\ Loyola University Chicago, phong@luc.edu
}

Stephen Wernet

Follow this and additional works at: https://ecommons.luc.edu/socialwork_facpubs

Part of the Social Work Commons

\section{Recommended Citation}

Hong, PYP and S Wernet. "Structural Reinterpretation of Poverty by Examining Working Poverty: Implications for Community and Policy Practice." Families in Society 88(3), 2007.

This Article is brought to you for free and open access by the Faculty Publications and Other Works by Department at Loyola eCommons. It has been accepted for inclusion in Social Work: School of Social Work Faculty Publications and Other Works by an authorized administrator of Loyola eCommons. For more information, please contact ecommons@luc.edu. c) $($ () $\ominus$

This work is licensed under a Creative Commons Attribution-Noncommercial-No Derivative Works 3.0 License. (c) Alliance for Children and Families, 2007. 


\title{
Structural Reinterpretation of Poverty by Examining Working Poverty: Implications for Community and Policy Practice
}

\author{
Philip Young P. Hong \& Stephen P. Wernet
}

\begin{abstract}
This exploratory research focused on the structural context of working poverty, thereby transcending its individual or behavioral aspects. Two major questions guided this study: (1) How are the working poor different compared to the working nonpoor? (2) How do structural conditions affect the chances of one being working poor? Central findings of the study were that four primary sets of factors-demographic, human capital, employment barriers, and labor market positionscontribute to an individual's likelihood of being among the working poor. The structural factorsemployment barriers and labor market positions-significantly contributed to the effects of human capital and demographic variables. All four factors require attention in community and policy practice to improve the lot of American workers in an increasingly global marketplace.
\end{abstract}

\section{Introduction}

A "reluctant welfare state" is an expression used to describe America's lack of public commitment to dealing with the comprehensive nature of poverty (Jansson, 2001). This is evidenced by the Personal Responsibility and Work Opportunity Reconciliation Act of 1996 (PRWORA; U.S. Public Law 104-193), also known as welfare reform, which transformed many former Aid to Families With Dependent Children (AFDC) recipients into participants of Temporary Assistance for Needy Families (TANF). At the heart of the legislation is devolving control over welfare to individual states and forcing recipients back to work after a two-year period of assistance, with an overall limit of 5 years of support in one's lifetime (U.S. House Ways and Means Committee, 2004). It essentially shifted the status of welfare recipients from being entitled to a safety net, or a cushion below which no one should fall, to being required to prove themselves as "deserving" recipients of any privileged benefits (Fitzgerald, 1998). Welfare has turned into workfare, with an increasing number of people exchanging their welfare payments for paychecks (Gueron, 1987; Melendez \& Harrison, 1998; Piven, 2003). Many individuals and families formerly known as the welfare poor have now become the working poor (Coon, Geo-Jaja, \& Mangum, 2000; Meyers \& Lee, 2003).

Lichter \& Jayakody (2002) stated that a decreased number of overall caseloads is an incomplete indicator for measuring success in welfare reform, and instead suggested using "improved well-being of America's poor families and children" (p. 119). One indicator of wellbeing that PRWORA promotes is "economic self-sufficiency" through work (Hawkins, 2005) based on obtaining living-wage jobs. Consequently, an assumption of welfare reform is that the labor market can absorb those leaving welfare for jobs (Blank, 1997). However, researchers who tracked people transitioning from welfare to work report that a sizable number of recipients were unable to keep jobs and tend to cycle between work and welfare (Bane \& Ellwood, 1994; Danziger, Corcoran, 
Danziger, \& Heflin, 2000; Harris, 1996; Kalil et al., 1998; Regenstein, Meyer, \& Hicks, 1998). In particular, women with little schooling, little work experience, and large families are more likely to return to welfare (Harris, 1996). Those for whom welfare is no longer an option often join the ranks of the working poor (Cheng, 2003).

As studies have pointed to increasing numbers of welfare exiters finding themselves in low-income jobs (Corcoran, Danziger, Kalil, \& Seefeldt, 2000; Coulton, 1996; Loprest, 1999; McCrate, 1997), the policy debate has gradually shifted from poverty to the "forgotten" or "invisible" working poor (Shipler, 2005). Relating welfare reform to working poverty has been encouraged by some studies (Albelda, 1999; Coon et al., 2000; Hong, 2004; O'Connor, 2000), and policymakers and policy analysts have become increasingly concerned about the challenges facing this segment of the poor (Acs, Phillips, \& McKenzie, 2000). Although poverty has lost ground as a public issue, a new focus on the working poor can help focus a policy debate that approaches poverty in a more comprehensive manner.

Examining the issue of working poverty is important for several reasons. First, it is a social justice, or "righteousness," issue (Shipler, 2005). The working poor are among the fastest growing segments of the poor, and this trend is projected to continue (Kim, 1998b; Rocha, 1997). When someone in America works hard and becomes, or remains, poor, America's strong emphasis on a work ethic and its dream for prosperity come into question.

Second, the working poor are economically vulnerable. They are twice as likely as other workers to become unemployed, and consequently experience economic hardships (Corcoran \& Hill, 1980). Poor workers and their families receive lower health care benefits due to access barriers (Ahmed, Lemkau, Nealeigh, \& Mann, 2001; Guendelman, Wyn, \& Tsai, 2002; Wolfe, 1994) and lower social security benefits upon retirement (Ozawa, 1982).

Third, economic vulnerability undermines family functioning. It increases psychological stress, which reduces family and marital satisfaction (Voydanoff \& Donnelly, 1988), and decreases the quality of parenting (Danziger \& Danziger, 1995; Dyk, 2004).

Fourth, economic difficulties hinder cognitive and socioemotional development of children (Korenman, Miller, \& Sjaastad, 1995). Children in working poor families are at greater risk for experiencing behavioral problems and academic failure (De Civita, Pagani, Vitaro, \& Tremblay, 2004).

This exploratory research investigated the structural conditions that contribute to the plight of the working poor. Two major questions guided this study: (1) How do the working poor differ from the working nonpoor by individual and structural correlates of poverty? (2) How do various structural conditions affect the chances of one being among the working poor? Working poverty focuses on everyone who is in the labor market. By keeping employment status constant, the worthiness of those who are poor is unquestionable. This allows us to investigate poverty among workers relative to their demographic and human capital characteristics, as well as employment barrier and labor market positions.

\section{Literature Review}

The behavioral revolution of the post-World War II era set forth the development of social knowledge rooted in individual and group behaviors (O'Connor, 2001). Therefore, the understanding of poverty today remains attached to individual characteristics (White, 1988). Individual explanations of poverty treat it as caused by individual choice or behavioral failings, and structural explanations locate its origins in economic and social arrangements (Burton, 1992; O'Connor, 2001; Rank, 1994).

There are four bodies of work that help inform our understanding the plight of the working poor. These bodies of literature discuss demographics, human capital, employment barriers, and split labor markets. The former two theoretical perspectives are considered individual factors, and the latter two are structural factors associated with poverty.

\section{Demographics of the Working Poor}

There is an array of demographic characteristics that affect estimates of the population of working poor. Every definition of working poor uses some combination of five demographics: age of the worker, length of time employed, income earned, type of employment, and eligibility for other assistance. Kim \& Mergoupis (1997) and Kim (1998b) used a definition of working poor that includes "anyone age 18 and older who worked at least one week during the four-month time period and who qualified for either Food Stamps or AFDC" (p. 708). Others defined working poor families as "those in which at least one parent worked 50 or more weeks during the year (or the family received child-support payments from a noncustodial parent), yet the family income was below the poverty line" (O'Hare \& Schwartz, 1997, p. 53). Schiller (1994) used a more stringent definition and considered only the poor persons who work full-time and full-year to be working poor. Schwartz \& Volgy (1992) used a similar definition, but loosened the poverty threshold to $155 \%$ of the federal poverty line. Another study (Acs et al., 2000) counted a family as poor "if its income falls below twice the federal poverty line and as working if the average annual hours worked by all adult family members exceeds 1,000 (approximately half-time)" (p. 1). These various definitions yield estimates of the working poor population as ranging between 2.5\% (Schiller, 1994) and 10\% (Kim, 1998b) of all workers. 
In 1989, Bruce Klein and Philip Rones of the U.S. Department of Labor's Bureau of Labor Statistics (BLS) developed a new measure for connecting individuals' labor market efforts to family poverty status (Gardner \& Herz, 1992). The working poor were defined as individuals 16 years and older "who spent at least 27 weeks in the labor force (working or looking for work), but whose incomes fell below the official poverty level" (BLS, 2002, p. 1). It was believed that a minimum period of 27 weeks is necessary "to develop meaningful linkages between an individual's work or work-seeking efforts and the economic status of the individual's family" (Gardner \& Herz, 1992, p. 20).

Using this BLS definition, about 7.8 million people, or $5.6 \%$ of those in the labor force, in 2004 were counted as working poor (BLS, 2006, p. 1). There has been a gradual increase in the number and percentage of working poor since 2000-6.8 million (4.9\%) in 2001, 7.4 million (5.3\%) in 2002, and 7.4 million (5.3\%) in 2003 (BLS, 2002, 2006). The proportions are slightly higher, and with a comparable trend, when looking at primary families, that is, the householder and all people living in the household who are related to the householder: 3.4 million (5.6\%) in 2000, 3.7 million (5.9\%) in 2001, 4.0 million $(6.3 \%)$ in 2002, 4.2 million $(6.6 \%)$ in 2003 , and 4.3 million (6.7\%) in 2004 . Therefore, the estimates of working poor in the United States are between $5.3 \%$ and $6.2 \%$ for the most recent years for which data are available.

The working poor

look much like other Americans. They live in marriedcouple families, are in prime working years, have at least a high school education, and work many hours (Kim \& Mergoupis, 1997). Unrelated individuals living together are more likely to be working poor, compared to those living alone (BLS, 2006). However, additional earners who provide between $\$ 2,000$ and $\$ 3,700$ each in earnings offset the increase in family needs attributable to an additional household member (Lerman, 2002). There is a nearly even split between women ( 4.0 million) and men (3.8 million) (BLS, 2006). About 53\%, or 4.1 million, of all working poor are between the ages of 16 and 34 . More than half of this group are non-Hispanic/Latino White (50.5\%), followed by Hispanic/Latino (24.7\%), African American (21.4\%), and Asian (3.4\%). Approximately $69 \%$ of working poor hold at least a high school diploma-approximately $31 \%$ do not have a high school diploma, $36 \%$ have only a high school degree, and 33\% have some type of postsecondary or collegiate education. The working poor are found in every occupational sector of the workforce: service (30.5\%); sales and office $(21.1 \%)$; natural resources, construction, and maintenance $(14.1 \%)$; production, transportation, and material moving (14.2\%); management, professional, and other related $(11.5 \%)$; and other $(8.6 \%)$.

\section{Human Capital and Working Poverty}

Although human capital theory cannot be reduced to a single theory, its essence is that the "people spend on themselves in diverse ways, not for the sake of present enjoyments, but for the sake of future pecuniary and nonpecuniary returns" (Blaug, 1976, p. 829). All individual purchases such as health, education, job search, information retrieval, migration, and in-service training may be regarded as human capital investment rather than consumption, whether individuals on their own behalf or society on behalf of its members made these purchases (Blaug, 1976) Classic studies of human investment analyses have focused on spending that would enhance an individual's future earnings capacity-migration (Sjaastad, 1962); health (Grossman, 1972); schooling (Becker, 1993; Schultz, 1965); on-the-job training (Mincer, 1962); job search (Spence, 1974); information evaluation (Stigler, 1962); and preschool investment in children (Leibowitz, 1972). Educated, skilled, and healthy individuals enjoy higher occupational status and earnings, thus raising their overall economic status. Often regarded as individual or behavioral attributes, the absence of human capital investment means less competitiveness in the labor market, which subsequently leads to poverty (Rank, 1994, pp. 26-27).

Recent studies continue to be dominated by the individual or behavioral focus on human capital. They support earlier findings that educational attainment is a strong predictor of individuals' economic well-being (Bane \& Ellwood, 1994; Barton \& Jenkins, 1995; Cancian, Haveman, Kaplan, \& Wolfe, 1999; Carr \& Lubitz, 1984; Danziger, Kalil, \& Anderson, 1998; Duncan \& Hoffman, 1988; Ellwood, 1986; Holzer, 1996; Klawitter, Plotnick, \& Edwards, 1996; Martinson, 2000; Rank, 1988; Zedlewski, 
1999). Job training is a pathway to better-paying jobs for many former welfare recipients and those working in poverty-rate jobs (Brodsky \& Ovwigho, 2002; Danziger et al., 1998). Research also recognizes that physical health characteristics co-occur with human capital problems among low-income people and impact their employment and earnings (Beverly \& Sherraden, 1997; Danziger et al., 1998; Jayakody, Danziger, \& Pollak, 2000; Kessler \& Frank, 1997; Olson \& Pavetti, 1996; Pindus, Koralek, Martinson, \& Trutko, 2000; Zedlewski, 1999).

\section{Employment Barriers and Working Poverty}

Recent research has focused on barriers to employment and their impact on the economic status of individuals and families. This focus evolved from concerns that job seekers facing multiple employment barriers experience limited marketability (Danziger, Corcoran, Danziger, Heflin, Kalil, et al., 2000). Barriers such as inadequate child care, limited transportation, and poor medical care are major obstacles to employment (Olson \& Pavetti, 1996). Kalil and colleagues (1998) reviewed the literature and identified numerous additional barriers: low level of schooling, little work experience, lack of job skills and credentials employers value, lack of "work readiness," worries about employer discrimination, mental health problems, alcohol and drug dependence, physical health problems, family stresses, and experiences of domestic violence.

Recent studies suggest welfare exiters face multiple employment barriers that are unaccounted for in the process of linking low-skilled or low-income job seekers with entry-level jobs (Loomis et al., 2003; Nam, 2005). And these barriers may be more persistent and longer lasting, which has implications for employment outcomes (Danziger \& Seefeldt, 2002). Research consistently supports child care as an employment barrier (Henly \& Lyons, 2000) along with transportation (Danziger, Corcoran, Danziger, Heflin, Kalil, et al., 2000), and health problems (Pavetti, Olson, Pindus, Pernas, \& Isaacs, 1996). State eligibility criteria for receipt of child care and transportation assistance require individuals to demonstrate these as barriers to participating in work-related activities.

\section{Split Labor Market and Working Poverty}

The split labor market theory posits that the poor do not participate in the mainstream economy and are excluded from jobs and income generated from this primary labor market (Doeringer \& Piore, 1971). This theory advances its argument based on Doeringer \& Piore's (1971) characterization of a primary labor market as one composed of jobs in large firms and/or unionized jobs, which tend to be better jobs-higher paying, more promotion possibilities, better working conditions, more stable work, equity, and due process in the administration of work rules
(Doeringer \& Piore, 1971). Rather than being employed in the primary labor market, the working poor participate in a separate and distinct labor market, that is, a secondary labor market. This market consists of low-paying jobs held by workers who have unstable working patterns and who are discriminated against (Cain, 1976). Jobs in the secondary market tend to have low wages, few fringe benefits, poor working conditions, high labor turnover, little chance of advancement, and, frequently, arbitrary and capricious supervision (Doeringer \& Piore, 1971).

Research focusing on the structural conditions of poverty and working poverty are limited in social work. Rank, Yoon, \& Hirschl (2003) provided a descriptive analysis of how lack of sufficient jobs could be a structural condition that affects the poverty status of individuals. In non-social work literature, Acs et al., (2000) reported that individuals in working poor families hold jobs that are in lower-status occupations- that is, less stable and providing fewer benefits-compared to their nonpoor counterparts. Kim (1998a, 1998b) also found that because of low wages, most working poor would remain poor even if they worked 40 hours per week for 52 weeks. Carrington \& Fallick's (2001) study supports these findings that "some workers will continue to be left behind in minimum wage careers" (p. 26).

\section{Hypotheses}

1. Demographic, human capital, employment barrier, and labor market position variables individually and as clusters affect the chances of being working poor, and

2. employment barrier and labor market position variables as clusters add to the effect of demographic and human capital variables.

\section{Methods}

\section{Sample}

This study used data from the Core and Topical Module files of the 1996 panel (12 waves started in April 1996 and ended in March 2000) of the Survey of Income and Program Participation (SIPP), from which the August 1998 time point was extracted. The SIPP is a primary source for poverty research because the data are compiled so that respondents' economic circumstances can be examined on a monthly basis. The SIPP consists of two different sets of questions-Core and Topical Modules. The Core questions are asked repeatedly every month and include demographic characteristics, labor force participation, income, earnings, and welfare participation. The Topical Module surveys produce detailed information on particular subjects. Data from Wave 8 (August-November 1998) of the 1996 panel is used for the main analyses. This particular wave was selected for cross-sectional analysis because it includes the welfare reform module questions 
that only appear in this wave. Some barrier variablesnamely, child care and transportation assistance denialwere taken from Topical Module 8, which corresponds with Wave 8 of the core data, for the analysis. The sample involved every working individual included in the SIPP sample in Wave 8 who was between the ages of 18 and 65 in August $1998(n=36,539)$.

\section{Variables}

Dependent variable. The dependent variable in this study was a measure of working poverty status among workingage adults who held a paid job during the reference period. Working poverty status was treated as a dichotomous variable indicating a currently employed individual's total household income in dollars relative to the official poverty line in August 1998. This measure was selected because the study focused primarily on the "deserving" individuals who were working at the time of study. A value of 0 was assigned for individuals who were identified as nonpoor, that is, having total household income greater than or equal to the poverty threshold, and 1 for those who were poor. As reported in the descriptive column of Table 1 , about $6.14 \%$ of the employed working-age adults in the sample were working poor. These people accounted for about $46.63 \%$ of the study's sample who lived below the poverty line.

Independent variables. Individual correlates of poverty were represented by the human capital independent variables. This variable set consisted of education, job training, and work-preventing health conditions. We created a nominal-level education variable with less than a high school degree being given the score of $1(9.65 \%)$. Job training was dichotomized, capturing whether a respondent received any job training between August 1988 and August 1998 (job training $=1 ; 42.66 \%$ ). Health was also dichotomized, capturing whether a respondent had workpreventing health conditions (both mental and physical) at the time of interview in August 1998. A value of 1 was assigned for individuals who reported having health problems (10.37\%) and 0 for those who did not.

Structural aspects of poverty were represented by two sets of independent variables in this study: employment barrier and labor market positions. The employment barriers variable set consisted of child care and transportation. Child care barrier was coded 1 if the respondent reported having received child care assistance from any sources, having left training or workfare programs due to child care problems, or having child care assistance cut or denied for any reasons $(.42 \%)$. All remaining cases were coded 0 . Similarly, transportation barrier was given the value of 1 for those who indicated they received transportation assistance from either the government or other sources, leaving training or workfare due to transportation problems, or being cut or denied transportation assistance (.18\%). Respondents who answered negatively to these questions were coded 0 .
The labor market position variable set consisted of minimum wage status, employer-sponsored health insurance, and employer-sponsored pension. A score of 1 was assigned if the adult workers had either received less than minimum hourly wage ( $\$ 5.15$ in 1998 ) or less than $\$ 840$ minimum monthly salary $(\$ 5.15 \times 40$ hours $\times 4$ weeks $)$ and 0 for those whose personal earnings fell above the threshold. About $18.44 \%$ of working adults in this sample were in jobs that paid less than minimum wage. Also indicative of job quality are employment benefits of employer-sponsored health insurance or pension plan, for which we used a score of 1 for these variables if the worker did not have them, $44.46 \%$ and $98.65 \%$, respectively. The remaining covered respondents were coded as 0 .

Demographic control variables. Representing individual characteristics of poverty, we included demographic factors that previous research suggests have significant effects on economic status. These factors included respondent's age, race, gender, marital status, number of children under 18 living in the household, and the presence of additional household earner(s). Respondent's age (mean = 38.96) and number of children under 18 living in the household (mean $=0.80$ ) were treated as continuous variables. The remaining variables were treated as dichotomous: race ( $15.07 \%$ non-White), gender ( $48.23 \%$ female), marital status (59.97\% married), and the presence of additional household earner(s) (72.44\%). Respondents who reported having additional earners who contributed more than $\$ 2,000$ annual income living with them received a score of 1 , and the remainder served as the reference group.

\section{Analysis}

Two types of statistics were estimated. ${ }^{1}$ First, bivariate $t$-tests were conducted to investigate the relationships between the individual and structural variables and working poverty status. Second, a series of multivariate logistic regression analyses ${ }^{2}$ were conducted, whereby working poverty status was regressed on the individual and structural variables as blocks of variables. We then examined the extent to which employment barriers and labor market position variables, when added as blocks to the human capital and demographic variables, influence working poverty status. To assess these effects, the log-likelihood ratio $(L R)$ tests $^{3}$ were conducted to examine whether there was a statistically significant improvement in the log-likelihood when the employment barriers and labor market position variables were sequentially added as blocks. Effects of each variable ${ }^{4}$ are reported using the final model.

\section{Findings}

\section{Bivariate Analyses}

Statistically significant differences were found between the working poor and the working nonpoor on all variables of interest (see Means Tests column in Table 1). 
A greater percentage of the working poor had less than a high school education as compared to the working nonpoor. The working poor had a lower percentage of individuals who reported having received some type of job training in the past 10 years. The working poor were more likely than the working nonpoor to have health conditions that prevented them from working. The working poor faced greater child care and transportation barriers. The portion of working poor who earned less than minimum wage, or minimum monthly salary, were greater than that of the working nonpoor. The working poor were unlikely to receive employer-sponsored health insurance and pension benefits. The working poor were more likely to be non-White, were younger, more likely to be women, more likely to be unmarried, and more likely to have children under 18 living in the household. The working poor had fewer additional household earners living with them.

\section{Multivariate Analyses}

A series of logistic regression models were examined to assess factors related to the probability of being working poor (see Table 2). Looking at each individual model separately, the analyses demonstrated good fits between the model and the data-human capital (HC) model $\left(\chi^{2}(3)\right.$ $=639.73, p<.001$ ), employment barrier (EB) model $\left(\chi^{2}(2)=131.74, p<.001\right)$, labor market positions (LMP) model $\left(\chi^{2}(3)=7125.84, p<.001\right)$, and demographic control (DC) model $\left(\chi^{2}(6)=2487.66, p<.001\right)$. These results indicate that each one of the four sets of independent variables improved prediction of an individual being among the working poor than a model without them.

Because DC and HC variables have been well documented in previous research as strong predictors of poverty status, these two blocks of variables were used as the base models to which EB and LMP were added in sequence. When EB was entered into the base model, this new model was found to be a good fit $\left(\chi^{2}(11)=3056.02\right.$, $p<.001)$. By using the LR test, a nested logistic regression

TABle 1. Descriptive Statistics and Means Tests

\begin{tabular}{|c|c|c|c|c|c|c|}
\hline \multirow[b]{2}{*}{ VARIABLES } & \multicolumn{3}{|c|}{$\begin{array}{c}\text { DESCRIPTIVE } \\
(\% \text { OF COLUMN VARIABLES })\end{array}$} & \multicolumn{3}{|c|}{$\begin{array}{c}\text { MEANS TESTS } \\
(\% \text { OF WORKING POVERTY) }\end{array}$} \\
\hline & ALL (\%) & $\begin{array}{l}\text { WORKING } \\
\text { NONPOOR }\end{array}$ & $\begin{array}{l}\text { WORKING } \\
\text { POOR }\end{array}$ & $\begin{array}{l}\text { WORKING } \\
\text { NONPOOR }\end{array}$ & $\begin{array}{l}\text { WORKING } \\
\text { POOR }\end{array}$ & SIG. \\
\hline Poverty (working and nonworking) & 10.78 & - & 46.63 & - & - & \\
\hline Unweighted $N^{\mathrm{a}}$ & 46,562 & & & & & \\
\hline \multicolumn{7}{|l|}{ Dependent variable } \\
\hline Working poor & 6.14 & 0.00 & 100.00 & - & - & \\
\hline \multicolumn{7}{|l|}{ Human capital variables } \\
\hline Education (<12 years) & 9.65 & 85.88 & 14.12 & 8.83 & 22.18 & $* * *$ \\
\hline Job training (received training) & 42.66 & 95.89 & 4.11 & 43.59 & 28.55 & $* * *$ \\
\hline Health (work-preventing conditions) & 10.37 & 87.38 & 12.62 & 9.65 & 21.29 & $* * *$ \\
\hline \multicolumn{7}{|l|}{ Employment barrier variables } \\
\hline Child care $^{\mathrm{b}}$ & .42 & 64.47 & 35.53 & .29 & 2.41 & $* * *$ \\
\hline Transportation $^{\mathrm{c}}$ & .18 & 71.21 & 28.79 & .14 & .85 & $* * *$ \\
\hline \multicolumn{7}{|l|}{ Labor market position variables } \\
\hline $\begin{array}{l}\text { Under minimum wage } \\
\text { Jobs without employer-sponsored }\end{array}$ & 18.44 & 78.67 & 21.33 & 15.45 & 64.01 & $* * *$ \\
\hline $\begin{array}{l}\text { health insurance benefits } \\
\text { Jobs without employer-sponsored }\end{array}$ & 44.46 & 90.10 & 9.90 & 42.68 & 71.63 & *** \\
\hline $\begin{array}{l}\text { pension benefits } \\
\text { Demographic control variables }\end{array}$ & 98.65 & 93.78 & 6.22 & 98.57 & 99.82 & $* * *$ \\
\hline Age (years) & $38.96(11.82)$ & - & - & $39.10(11.83)$ & ) $36.72(11.46)$ & $* * *$ \\
\hline Non-White & 15.07 & 89.63 & 10.37 & 14.39 & 25.43 & $* * *$ \\
\hline Female & 48.23 & 93.37 & 6.63 & 47.99 & 52.03 & $* * *$ \\
\hline Married & 59.97 & 95.38 & 4.62 & 60.95 & 45.12 & $* * *$ \\
\hline Number of children & $.80(1.10)$ & - & - & $.77(1.07)$ & $1.31(1.45)$ & $* * *$ \\
\hline Additional household earner(s) & 72.44 & 97.21 & 2.79 & 75.03 & 32.92 & $* * *$ \\
\hline Unweighted $N^{\mathrm{d}}$ & 36,539 & 34,294 & 2,245 & 34,294 & 2,245 & \\
\hline
\end{tabular}

Note. * indicates significantly different from not poor population at $p<.05$, ** indicates $p<.01$, and *** indicates $p<.001$; and standard deviations are in parentheses for continuous variables.

as sample of all working-age adults in August 1998.

${ }^{b}$ Child care assistance received, cut, or denied.

c Transportation assistance received, cut, or denied.

d As sample of people who were working in August 1998 including both those who were nonpoor (working poverty =0) and poor (working poverty = 1). 
model that only included DC and HC variables was compared with the unconstrained model that added a block of EB variables. The results showed that removing the EB variables from the new unconstrained model significantly reduced the log likelihood value $\left(\chi^{2}(2)=26.34, p<.001\right)$. In other words, including EB information improved prediction of an individual being among the working poor over the nested model using only DC and HC variables.

Next, the LMP variables were introduced to the model that consisted of $\mathrm{HC}, \mathrm{EB}$, and $\mathrm{DC}$ variables. This full model was found to be significant indicating a good fit $\left(\chi^{2}(14)=5740.05, p<.001\right)$. The full model incorporating the four variable sets was significantly better than the partial model excluding the LMP variables $\left(\chi^{2}(3)=2684.03\right.$, $p<.001)$. These findings confirm that the EB and LMP variables are important components for explaining the likelihood of being working poor.

In the full model, all $\mathrm{HC}$ variables-education, job training, and health-significantly differentiated one's status as among the working poor. Holding all other vari-

TABLE 2. Multivariate Logistic Regression Analyses

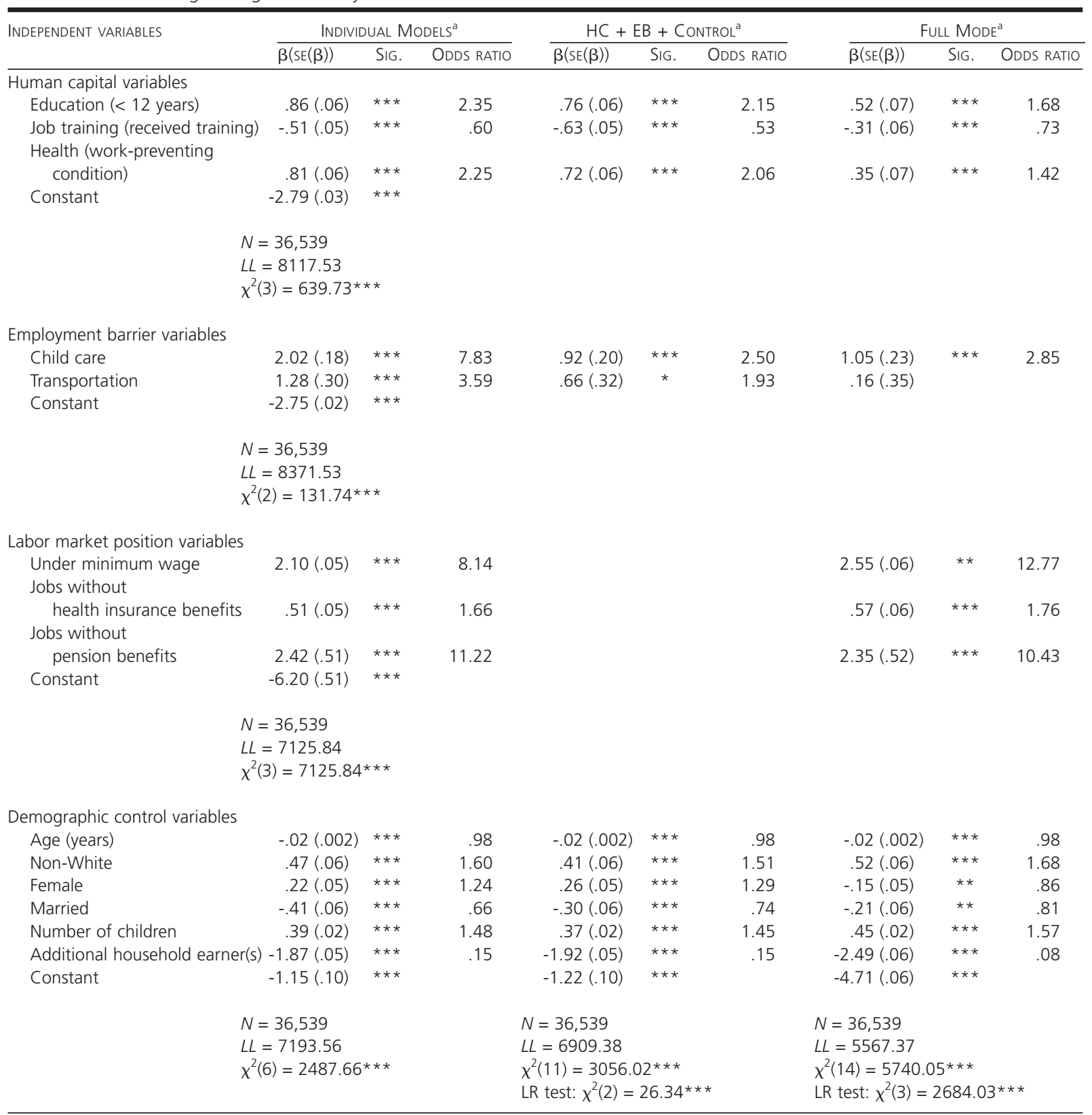

Note. * indicates $p<.05, * *$ indicates $p<.01$, and $* * *$ indicates $p<.001$.

${ }^{a}$ Dependent variable (working poverty) $=(0)$ working and nonpoor, $(1)$ working poor. 
ables constant, the adjusted odds of being working poor for individuals with less than a high school degree were $76 \%$ greater than the odds for those without a high school degree. The odds of being working poor for individuals who had received some job training were $27 \%$ lower than those who had not. The odds of being working poor for those with health conditions that prevented them from working were $42 \%$ higher compared to those who maintained good health conditions. Therefore, low educational achievement, absence of job training and presence of health problems increases the likelihood of a person being among the working poor.

In the full model, the EB variables yielded mixed results. Only the child care barrier significantly increased the likelihood of being working poor. The predicted odds of individuals with a child care barrier to be in the working poor were 2.85 times greater than those who did not experience this barrier. Interestingly, the effect of the transportation barrier was eliminated as the LMP variables were introduced into the model. While transportation served as a significant barrier in the previous two models, it no longer was significant when included in the full model.

Particularly pronounced in this study were the effects of LMP variables. All three variables in the LMP set significantly increased the chances of one being working poor. Having a job that pays less than minimum wage increased the predicted odds of being working poor by 12.77 times. The odds of being working poor for those who did not have jobs that provided health insurance were $76 \%$ higher than their counterparts with employersponsored health insurance. Having a job that does not offer pension plans also significantly increased the likelihood 10.43 times that the individual is among the working poor.

When examining the DC variables, younger adults and those who had more children living in the household had greater likelihood of being working poor. The adjusted odds of non-White individuals being working poor were $68 \%$ higher than the odds for White individuals. Surprisingly, being female was associated with $14 \%$ lower odds of being working poor compared to male counterparts. In the previous models, the relationships pointed in the opposite direction. Unmarried individuals were more likely to be working poor. Having another household earner(s) with more than $\$ 2,000$ annual income was associated with $92 \%$ lower odds of being working poor.

\section{Discussion}

Two research questions guided this study - the first having to do with the characteristics of the working poor and the second investigating the conditions affecting one's chance of being working poor. Regarding our first question, approximately $6.14 \%$ of all respondents were identi- fied as working poor, and this figure is consistent with other estimates. It is somewhere between the 2004 BLS (2006) estimate (5.6\%) and that found by Kim (1998a) (7\%). Many people are profoundly affected by the problem of working poverty. It appears that many families in contemporary America are struggling to survive. The working poor constitute a sizable portion of all adults, both working and nonworking, living in poverty $(46.63 \%)$.

The working poor are distinguishable from the working nonpoor on virtually every variable of interest in this study. They are disadvantaged personally as well as structurally. Personally, they are starting the earnings race well behind others, and with additional weights that inhibit their success. The working poor are younger, unmarried, and non-White; have children under 18; and have only their own earnings as financial support. They have fewer human capital resources than the working nonpoor, that is, less education, less on-the-job training, and more health problems. These working poor face greater challenges with child care, receive minimum wage or less and receive neither employer-sponsored health care nor pension benefits.

Regarding our second research question, the findings both support and extend existing literature on poverty. There are both individual features as well as structural factors that increase one's likelihood of becoming part of the working poor. Although each set of variables explains working poverty, together they provide a more complete and complex picture of the situation facing the working poor. Taken individually, these factors can be used in the rhetoric for blaming someone for working poverty. Taken together, working poverty emerges as a mosaic constructed from an array of multiple factors blending into a multidimensional picture, requiring shared responsibility for solution.

Our findings point to interesting implications regarding the structural issues surrounding the working poor. Structural variables-both employment barriers and labor market positions-significantly increase the effects of demographic characteristics and human capital variables for predicting the likelihood of being among the working poor. In particular, the labor market position variables provide additional evidence for refocusing social and public policy concerning the Federal minimum wage and universal health care. To raise people out of working poverty, it is necessary to ensure economic security in the present. This can only be achieved through raising the federal minimum wage and providing some form of basic, universal health care. To ensure future economic security, pension plans must also be guaranteed for employees but not at the expense of present wages. This is not an either/or but rather an and proposition.

Some of the demographic characteristic variables deserve additional attention. The gender effect on working poverty in the full model switched directions from the 
partial models. This result supports Mosisa's (2003) finding that working women are less likely than working men to be poor because they are more likely to be in families with a second earner. Because this relationship was not found in the partial models that also controlled for having additional earners in the household, we speculate that the effect of gender inequality was no longer present in the model after removing the effect of being disproportionately located in low-wage labor market. One can only speculate whether women who earned less than minimum wage/salary adapted better than their male counterparts during a downward job restructuring in the U.S. economy-namely, the decline of manufacturing jobs and the growth of service sector jobs (Craypo \& Cormier, 2000). However, this interpretation may not hold when looking at ethnicity. Non-Whites consistently experienced greater odds of being working poor. Because globalization will continue eliminating manufacturing jobs at lower wage levels in the United States, the interplay of gender and race will need to be reexamined.

One of the four goals of welfare reform is to promote two-parent families, suggesting that it will reduce poverty (U.S. House Ways and Means Committee, 2004). This gave rise to the healthy marriage initiative to provide a strong foundation for child development and successful society. Our findings are consistent with this marriage initiative: Married workers are less likely to be working poor. It would appear that the beneficiary for this initiative is low-income working individuals who could move out of poverty by forming healthy families. However, the findings do not confirm this causal link. Individuals in higher economic status, who could afford to get married in the first place, may have found comparable partners in the higher-income marriage market, and therefore with combined income they could have ended up in the nonworking poor group. Healthy marriage is not a simple equation of adding two income sources; rather, it represents a balance of interrelated psychosocial and economic resources. Without support for job training, education, health care, child care, and creating good jobs, promoting marriage alone makes for poor long-term social policy, which undermines attainment of self-sufficiency among the working poor.

The human capital factor-education, job training, and health-consistently distinguishes those in working poverty. Understood more as individual characteristics, human capital development (HCD) practices have been an anathema to the current bootstrap approach (Iversen \& Armstrong, 2006). Piecemeal, short-sighted, and poorly funded programs rather than comprehensive, empowering practices have prevailed because employers tend to be more concerned with higher costs, longer completing time, and higher dropout rates in HCD practices (Freedman, Mitchell, \& Navarro, 1998; Hamilton, Brock, Farrell, Friedlander, \& Harknett, 1997). This may be attributable to the structure of the labor market not rewarding individual decisions to invest in human capital. Accordingly, Hong \& Pandey (2007) find that human capital variables are structurally vulnerable attributes among American poor, as these seemingly individual characteristics co-occur with their structural underemployment status. As Rank (2004) would suggest, human capital accumulation is only an individual reflection of structural vulnerability, often exacerbated by discrimination in employers' hiring practices (Sunstein, 1997) and job segregation and lack of opportunities (Tomaskovic-Dovey, 1993).

Therefore, HCD should not be a model for marginal individual development (i.e., training for low-wage jobs); rather it ought to be considered in the context of social capital development (Zippay, 2001) and community, business, and education partnerships (Hong, Naeger, \& Sheriff, 2006; Iversen \& Armstrong, 2006). This highlights the need for renewed interest in and emphasis on lifelong learning shared by all parties - the individual, the public sector and the private sector-so as to retain America's competitive place in a globalized economy. If the working poor are to rise into the middle class, and realize the American dream, then they require long-term, lifelong investment in their future, which is also the future of American society.

The lack of child care and transportation as barriers to employment yielded mixed results. In the partial model, both barriers were significant determinants of working poverty. However, transportation fell out when LMP variables were added into the full model. We attribute this to employment barriers coming in two forms, one having to do with employees' conditions (the supply side) and the other with employers' conditions (the demand side) of the labor market. Although child care barriers may be a supply-side issue, it is structural when the cost and the quality of child care cannot be matched with the rising needs of the working poor, and in markets where affordable, quality child care is in short supply. This interpretation may hold when considering that federal funding supports of affordable child care go primarily to middleincome and nonemployed parents and not to working poor and working-class parents (Hofferth, 1999). Transportation should also be considered a demand-side condition (i.e., job sprawl) rather than a supply-side barrier (i.e., not having a car), which may explain its absence from the full model. The spatial mismatch between the residence of working poor families and the location of employment opportunity in the suburbs (Lambert, 1998; Stoll, 2006) speak to the demand-side barrier resulting from labor market conditions rather than the absence of personal resources.

Of major interest in these findings is the role of the labor market position factor. These labor market positions as represented by minimum wage and employer-provided 
health insurance and pension reflect a position in the labor market that contributes to one's likelihood of being working poor. These findings are consistent with the previous economic and public policy studies that highlight increasing dead-end secondary labor market jobs as contributing to one's chance of being working poor (Craypo \& Cormier, 2000; Jensen \& Slack, 2003; Kim, 1998b). The presence of subpar, labor market positions leading to working poverty may need to be redefined and reconceptualized as a form of discrimination and social exclusion (Estivill, 2003). These labor market positions affect not only present but also future social conditions, essentially marginalizing and disenfranchising the working poor.

Common individually based policy responses to working poverty are supporting and sustaining self-sufficiency through the Workforce Investment Act of 1998 (WIA; U.S. Public Law 105-220), and expanding the refundable tax credit to low-wage earners through the Earned Income Tax Credit (EITC). However, we suggest that these will not have much bearing if the structure of the labor market is not sufficiently targeted through raising the minimum wage and ensuring universal health care and pension plans. In other words, investing in the quality of the labor market rather than the quality of individual workers is what this article presents as the new focus of policy practice. This is possible when a manageable labor market structure at the community level is altered to better include the needs of workers.

Although this study provides some interesting results, there are several limitations. This was a cross-sectional analysis limited to a point-in-time description of working poverty. Unfortunately, to our knowledge, no large-scale nationally representative longitudinal data exist covering all domains of theoretical perspectives examined in this study. Developing longitudinal data sets that include the full range of perspectives could allow better tests for the comprehensive nature of working poverty. The use of employment barriers variables in the SIPP led us to use the 1998 time-point, and more needs to be done to understand barriers to employment by using newer data. The variables themselves have limitations. The size of those who identified these barriers were small, possibly either inflating or depressing the impact of these factors on our models. Finally, large-scale studies such as this one may assume that all working poor are the same by putting them into the same working poor category. Understanding that working poverty comes with many complex situations in family life (Dyk, 2004), more community-based studies need to be conducted using the definition that best suits the local economy.

\section{Conclusion}

This study highlighted structural factors that contribute to workers being among the working poor. The logic of contemporary social policy is one that underwrites lowwage work and job migration in a changing, global labor market (Friedman, 2005; Piven, 2003). Over this past century, poverty in the United States has been redefined as an individual rather than a structural or societal issue. Consequently, public and government policy has emphasized, reinforced, and rewarded individually focused responses. In other words, the American social response to poverty has been focused on the private good.

However, social well-being in general, and family wellbeing in particular, is "a product of the larger economic, social, and political world in which families are embedded [and] their own interior worlds of development and relationships" (Chilman, 1991, p. 191). Examining labor market conditions as an externality helps shift the understanding of factors contributing to one's economic status from individual to structural phenomenon. Therefore, building an antipoverty agenda in the United States will "require a basic change in the way we as a society think collectively about the poverty problem" (O'Connor, 2001, p. 4). To "make capitalism work" the American response must resurrect a social or common-good response.

A common-good response is defined by several features. It emphasizes social cooperation and an environment in which people are not excluded from activities of society. It provides equal access to opportunity. It emphasizes a socially just treatment for the most vulnerable in our society. It defines public goods as indivisible. It helps the greatest possible number of people. It fosters the sense of belonging and interconnectedness. It creates the common hope that society can do better by having all members do better.

More specifically, a common-good response will target structural barriers that interfere with and inhibit the social well-being of all, and especially the most vulnerable Americans. Effective policy measures to address the common good include redefining employment and labor market barriers from individual responsibilities to shared, public problems. These measures entail public policy solutions that provide child care, transportation, and housing subsidies for all Americans, especially the working poor. Indirect interventions that stimulate and reward individuals, such as tax credits, may work in some situations, and asset-development strategies and initiatives will be necessary in others. However, direct intervention of an activist government will be necessary in some communities to facilitate a common-good, public response to a social need. Measures such as raising the minimum wage through the Living Wage Campaign, guaranteeing affordable quality secondary and post secondary education as well as lifelong learning opportunities, and assuring universal health care are commongood problems requiring public or social policy responses. Common-good solutions that encourage the upward, economic mobility for the most vulnerable will 
help insure the security of all Americans thereby building a strong and secure America.

As essential as these policy measures are, efforts will bear little fruit if they only play catch up in a system that continues to exclude the working poor, other vulnerable working, near-poor and increasingly a vulnerable middle class. America requires a new social contract for and among its citizens. Each of us is only as secure as our neighbor. The world is flat and our futures are tied together (Freidman, 2005). As Rocha (1997) suggests, the solution is "promoting community-focused strategies by empowering workers with increased skills and by expanding social and economic opportunities" (p. 337). The common-good is difficult to realize in large institutional arrangements as individuals are estranged from one another and corporations increasingly play communities and nations against each other.

In today's interlocking and interdependent world, an individual's security is dependent on others. Large organizations such as the capitalist system or governments need to behave like a related group of small organizations (Schumacher, 1973). In this regard, workforce development and community-based labor market development need to be strategically combined across the local level into a network of economic opportunity and security. Social workers must return to the center of organizing citizens and communities to develop this common-good response. Social workers can facilitate a cooperative process for creating opportunities through strengthsbased resource pooling through which people will have a claim on this common good as an empowered member of the community.

\section{References}

Acs, G., Phillips, K. R., \& McKenzie, D. (2000). Playing by the rules but losing the game: America's working poor (Report Pub. ID\# 410404). Washington, DC: The Urban Institute.

Ahmed, S. M., Lemkau, J. P., Nealeigh, N., \& Mann, B. (2001). Barriers to healthcare access in a non-elderly urban American population. Health \& Social Care in the Community, 9(6), 445-453.

Albelda, R. (1999). What welfare reform has wrought. Dollars \& Sense, $221,15-18$.

Bane, M., \& Ellwood, D. (1994). Welfare realities: From rhetoric to reform. Cambridge, MA: Harvard University Press.

Barton, P., \& Jenkins, L. (1995). Literacy and dependency: The literacy skills of welfare recipients in the United States. Cambridge, MA: Harvard University Press.

Becker, G. (1993). Human capital. (3rd ed.). Chicago: University of Chicago Press.

Beverly, S., \& Sherraden, M. (1997). Human capital and social work (Working Paper 92-2). Saint Louis, MO: Washington University, Center for Social Development.

Blank, R. (1997). It takes a nation: A new agenda for fighting poverty. Princeton, NJ: Princeton University Press.

Blaug, M. (1976). The empirical status of human capital theory: A slightly jaundiced survey. Journal of Economic Literature, 14(3), 827-855.

Brodsky, A., \& Ovwigho, P. C. (2002). Swimming against the tide: connecting low-income women to living wage jobs. Journal of Poverty, 6(3), 63-88.
Burton, E. (1992). The poverty debate: Politics and the poor in America. Westport, CT: Greenwood Press.

Cain, G. (1976). The challenges of segmented labor market theories to orthodox theory: A survey. Journal of Economic Literature, 14(4), 1215-1257.

Cancian, M., Haveman, R., Kaplan, T., \& Wolfe, B. (1999). Post-exit earnings and benefits receipt among those who left AFDC in Wisconsin (Special Report No. 75). Madison, WI: University of Wisconsin-Madison, Institute for Research on Poverty.

Carr, T., \& Lubitz, S. (1984, August). An analysis of turnover in the Food Stamp program. Paper presented at the Annual Meeting of the American Statistical Association, Philadelphia, PA.

Carrington, W. J., \& Fallick, B. C. (2001). Do some workers have minimum wage careers? Monthly Labor Review, 124(5), 17-27.

Cheng, T. C. (2003). Welfare "recidivism" among former welfare recipients. Families in Society, 84(1), 63-74.

Chilman, C. (1991). Working poor families: Trends, causes, effects, and suggested policies. Family Relations, 40(2), 191-198.

Coon, A., Geo-Jaja, M., \& Mangum, G. (2000). Welfare reform initiative: From welfare poor to working poor: Post AFDC/TANF income in the state of Utah. Salt Lake City, UT: University of Utah, Center for Public Policy and Administration.

Corcoran, M., Danziger, S., Kalil, A., \& Seefeldt, K. (2000). How welfare reform is affecting women's work. Annual Review of Sociology, 26, 241-269.

Corcoran, M., \& Hill, M. S. (1980). Unemployment and poverty. Social Service Review, 54(3), 407-413.

Coulton, C. J. (1996). Poverty, work and community: A research agenda for an era of diminishing federal responsibility. Social Work, 41(5), $509-519$.

Craypo, C., \& Cormier, D. (2000). Job restructuring as a determinant of wage inequality and working-poor households. Journal of Economic Issues, 34(1), 21-42.

Danziger, S., Corcoran, M., Danziger, S., \& Heflin, C. (2000). Work, income, and material hardship after welfare reform. Journal of Consumer Affairs, 34(1), 6-30.

Danziger, S., Corcoran, M., Danziger, S., Heflin, C., Kalil, A., Levine, J., et al. (2000). Barriers to the employment of welfare recipients. Ann Arbor, MI: University of Michigan, Poverty Research \& Training Center.

Danziger, S., \& Danziger, S. (1995). Child poverty, public policy and welfare reform. Children and Youth Services Review, 17(1/2), 1-10.

Danziger, S. F., \& Seefeldt, K. S. (2002). Barriers to employment and the "hard to serve": Implications for services, sanctions, and time limits. Focus, 22(1), 76-81.

Danziger, S., Kalil, A., \& Anderson, N. (1998). Human capital, health and mental health of welfare recipients: Co-occurrence and correlates. Journal of Social Issues, 54(4), 637-656.

De Civita, M., Pagani, L., Vitaro, F., \& Tremblay, R. E. (2004). The role of maternal educational aspirations in mediating the risk of income source on academic failure in children from persistently poor families. Children and Youth Services Review, 26(8), 749-769.

Doeringer, P., \& Piore, M. (1971). Internal labor markets and manpower analysis. Lexington, MA: Heath Lexington Books.

Duncan, G., \& Hoffman, S. (1988). The use and effects of welfare of welfare recipients: A survey of recent evidence. Social Service Review, 62, 238-257.

Dyk, P. H. (2004). Complexity of family life among the low-income and working poor: Introduction to the special issue. Family Relations, 53(2), 122-126.

Ellwood, D. (1986). Working off welfare: Prospects and policies for selfsufficiency of women heading families (Discussion Paper 803-86). Madison, WI: University of Wisconsin-Madison, Institute for Research on Poverty.

Estivill, J. (2003). Concepts and strategies for combating social exclusion: An overview. Portugal: International Labour Office.

Fitzgerald, S. (1998). The poverty of welfare reform. Policy Studies Journal, 26(2), 333-341. 
Freedman, S., Mitchell, M., \& Navarro, D. (1999). The Los Angeles JobsFirst GAIN evaluation: Preliminary findings on participation patterns and first-year impacts. New York: Manpower Demonstration Research Corporation.

Friedman, T. (2005). The world is flat: A brief history of the twenty-first century. New York: Farrax, Straus and Gibson.

Gardner, J., \& Herz, D. (1992). Working and poor in 1990. Monthly Labor Review, 115(12), 20-28.

Grossman, M. (1972). The demand for health: A theoretical and empirical investigation. New York: Columbia University Press, National Bureau or Economic Research.

Guendelman, S., Wyn, R., \& Tsai, Y. (2002). Children of working poor families in California: The effects of insurance status on access and utilization of primary health care. Journal of Health \& Social Policy, $14(4), 1-20$.

Gueron, J. (1987). Reforming welfare with work. New York: Ford Foundation.

Hamilton, G., Brock, T., Farrell, M., Friedlander, D., \& Harknett, K. (1997). Evaluating two welfare-to-work program approaches: Two year findings on the labor force attachment and human capital development programs in three sites. New York: Manpower Demonstration Research.

Harris, K. (1996). Life after welfare: Women, work, and repeat dependency. American Sociological Review, 61, 407-426.

Hawkins, R. L. (2005). From self-sufficiency to personal and family sustainability: A new paradigm for social policy. Journal of Sociology and Social Welfare, 32(4), 77-92.

Henly, J. R., \& Lyons, S. (2000). The negotiation of child care and employment demands among low-income parents. Journal of Social Issues, 56(4), 683-706.

Hofferth, S. L. (1999). Child care, maternal employment, and public policy. The Annals of the American Academy of Political and Social Science, 563, 20-38.

Holzer, H. (1996). What employers want: Job prospects for less-educated workers. New York: Russell Sage Foundation.

Hong, P. Y. (2004). Poverty in the United States: Examining the effects of human capital, welfare dependency, and employment barrier perspectives. (Doctoral dissertation, Washington University in St. Louis, 2003). Dissertation Abstracts International, 64, 9A.

Hong, P. Y., Naeger, S., \& Sheriff, A. (2006, June). Towards a socially just definition of self-sufficiency: Voices from low-income jobseekers. Paper presented at the 2006 Policy Conference, Washington, DC

Hong, P. Y., \& Pandey, S. (2007). Human capital as structural vulnerability of U.S. poverty. Equal Opportunities International, 26(1), 18-43.

Iversen, R. R., \& Armstrong, A. L. (2006). Jobs aren't enough: Toward a new economic mobility for low-income families. Philadelphia, PA: Temple University Press.

Jansson, B. S. (2001). The reluctant welfare state. Pacific Grove, CA: Brooks/Cole.

Jayakody, R., Danziger, S., \& Pollak, H. (2000). "Welfare reform, substance abuse, and mental health." Journal of Health Politics, Policy, and Law $25,623-651$.

Jensen, L., \& Slack, T. (2003). Underemployment in America: Measurement and evidence. American Journal of Community Psychology, 32(1/2), 21-31.

Kalil, A., Corcoran, M., Danziger, S., Tolman, R., Seefeldt, K., Rosen, D., et al. (1998). Getting jobs, keeping jobs, and earning a living wage: Can welfare reform work? Madison, WI: University of WisconsinMadison, Institute for Research on Poverty.

Kessler, R., \& Frank, R. (1997). The impact of psychiatric disorder on work loss days. Psychological Medicine, 27, 861-873.

Kim, M. (1998a). Are the working poor lazy? Challenge, 41(3), 85-99.

Kim, M. (1998b). The working poor: Lousy jobs or lazy workers? Journal of Economic Issues, 32(1), 65-89.

Kim, M., \& Mergoupis, T. (1997). The working poor and welfare recipiency: Participation, evidence, and policy directions. Journal of Economic Issues, 31(2), 707-729.
Klawitter, M., Plotnick, R., \& Edwards, M. (1996). Determinants of welfare entry and exit by young women (Discussion Paper 1099-96). Madison, WI: University of Wisconsin-Madison, Institute for Research on Poverty.

Korenman, S., Miller, J., \& Sjaastad, J. (1995). Long-term poverty and child development in the United States: Results from the NLSY. Children and Youth Services Review, 17(1/2), 127-155.

Lambert, T. E. (1998). The poor and transportation. Journal of Economic Issues, 32(4), 1140-1142.

Leibowitz, A. S. (1972). Women's allocation of time to market and nonmarket activities: Differences by education (Doctoral dissertation, Columbia University, 1972). Dissertation Abstracts International, 33 $6 \mathrm{~A}$.

Lerman, R. (2002). How do marriage, cohabitation, and single parenthood affect the material hardships of family with children? Washington, DC: The Urban Institute.

Lichter, D., \& Jayakody, R. (2002). Welfare reform: How do we measure success? Annual Review of Sociology, 28, 117-141.

Loomis, C., Brodsky, A. E., Arteaga, S. S., Benhorin, R., Rogers-Senuta, K., Marx, C. M., et al. (2003). What works in adult educational and employment training? Case study of a community-based program for women. Journal of Community Practice, 11(2), 27-45.

Loprest, P. (1999). Families who left welfare: Who are they and how are they doing? Assessing the new federalism (Discussion Paper 99-02). Washington, DC: The Urban Institute.

Martinson, K. (2000). The national evaluation of welfare-to-work strategies: The experiences of welfare recipients who find jobs. U.S. Department of Health and Human Services, Administration for Children and Families Office of the Assistant Secretary for Planning and Evaluation.

McCrate, E. (1997). Welfare and women's earnings. Politics and Society, 25(4), 417-442.

Melendez, E., \& Harrison, B. (1998). Matching the disadvantaged to job opportunities: Structural explanations for the past successes of the Center for Employment Training. Economic Development Quarterly 12(1), 3-11.

Meyers, M. K., \& Lee, J. M. (2003). Working but poor: How are families faring? Children and Youth Services Review, 25(3), 177-201.

Mincer, J. (1962). On-the-job training: Costs, returns, and some implications. Journal of Political Economy, 50(5), 50-79.

Morrow-Howell, N., \& Proctor, E. (1992). The use of logistic regression in social work research. Journal of Social Service Research, 16, $87-104$.

Mosisa, A. T. (2003). The working poor in 2001. Monthly Labor Review, $126,11-12$.

Nam, Y. (2005). The roles of employment barriers in welfare exits and reentries after welfare reform: Event history analyses. Social Service Review, 79(2), 268-93.

O'Connor, A. (2000). Poverty research and policy for the post-welfare era. Annual Review of Sociology, 26, 547-562.

O'Connor, A. (2001). Poverty knowledge: Social science, social policy, and the poor in the twentieth-century U.S. history. Princeton, NJ: Princeton University Press.

O'Hare, W., \& Schwartz, J. (1997). One step forward, two steps back: The working poor. American Demographics, 19(9), 53-56.

Olson, K., \& Pavetti, L. (1996). Personal and family challenges to the successful transition from welfare to work. Washington, DC: The Urban Institute.

Ozawa, M. N. (1982). Who receives subsidies through social security, and how much? Social Work, 27, 129-134.

Pavetti, L., Olson, K., Pindus, N., Pernas, M., \& Isaacs, J. (1996). Designing welfare-to-work options for families facing personal and family challenges: Rationale and program strategies. Washington, DC: The Urban Institute.

Pindus, N., Koralek, R., Martinson, K., \& Trutko, J. (2000). Coordination and integration of welfare and workforce development system. Washington, DC: The Urban Institute.

Piven, F. F. (2003). Neo-liberal social policy and labor market discipline. Journal of Poverty, 7(3), 1-11. 
Rank, M. R. (1988). Racial differences in length of welfare use. Social Forces, 66, 1080-1101.

Rank, M. R. (1994). Living on the edge: The realities of welfare in America. New York: Columbia University Press.

Rank, M. R. (2004). One nation underprivileged: Why American poverty affects us all. New York: Oxford University Press.

Rank, M. R., Yoon, H., \& Hirschl, T. (2003). American poverty as a structural failing: Evidence and arguments. Journal of Sociology and Social Welfare, 30(4), 3-29.

Regenstein, M., Meyer, J. A.,\& Hicks, J. D. (1998). Job prospects for welfare recipients: Employers speak out. Assessing the new federalism (Occasional Paper 10). Washington, DC: The Urban Institute.

Rocha, C. (1997). Working poor. In R. L. Edwards (Ed.-in-Chief), Encyclopedia of social work (19th ed., 1997 Supplement, pp. 77-89). Washington, DC: NASW Press.

Schiller, B. (1994). Who are the working poor? The Public Interest, 115, $61-71$.

Schultz, T. (1965). Investing in poor people: An economist's view. American Economic Review, 55(2), 510-520.

Schumacher, E. F. (1973). Small is beautiful: Economics as if people mattered. New York: Harper\& Row.

Schwartz, J. E., \& Volgy, T. J. (1992). The forgotten Americans. New York: WW Norton.

Shipler, D. K. (2005). The working poor: Invisible in America. New York: Vintage Books.

Sjaastad, L. (1962). The costs and returns of human migration. Journal of Political Economy, 70(5), 80-93.

Spence, A. (1974). Market signaling. Cambridge, MA: Harvard University Press.

Stigler, G. (1962). Information in the labor market. Journal of Political Economy, 70(5), 94-105

Stoll, M. A. (2006). Job sprawl, spatial mismatch, and black employment disadvantage. Journal of Policy Analysis and Management, 25(4) $827-854$.

Sunstein, C. R. (1997). Free markets and social justice. New York: Oxford University Press.

Tomaskovic-Dovey, D. (1993). Gender \& racial inequality at work: The sources \& consequences of job segregation. Ithaca, NY: ILR Press.

U.S. Bureau of Labor Statistics (BLS). (2002, May). A profile of the working poor, 2000. Washington, DC: U.S. Department of Labor.

U.S. Bureau of Labor Statistics (BLS). (2006, May). A profile of the working poor, 2004. Washington, DC: U.S. Department of Labor.

U.S. House Ways and Means Committee. (2004, August). 2004 Green Book. (Publication No. WMCP 108-6). Retrieved September 7, 2006, from House Ways and Means Committee Prints: Main Page via GPO Access: www.gpoaccess.gov/wmprints/green/2004.html

Voydanoff, P., \& Donnelly, B. W. (1988). Economic distress, family coping and quality of family life. In P. Voydanoff \& L. C. Majka (Eds.), Family and economic distress: Coping strategies and social policy (pp. 97-116). Newbury Park, CA: Sage.

White, J. (1988). The new politics of old values. London: University Press of New England.
Wolfe, B. L. (1994). Reform of health care for the nonelderly poor. In S. H. Danziger, G. D. Sandefur, \& D. H. Weinberg (Eds.), Confronting poverty: Prescriptions for change (253-288). New York: Howard University Press.

Zedlewski, S. (1999). Work-related activities and limitations of current welfare recipients. Assessing the new federalism (Discussion Paper 99-06). Washington, DC: The Urban Institute.

Zippay, A. (2001). The role of social capital: A longitudinal study of occupational mobility among displaced steelworkers. Journal of Sociology and Social Welfare, 28 (4), 99-119.

Philip Young P. Hong, PhD, is assistant professor, Loyola University Chicago School of Social Work, 820 N. Michigan Ave., Chicago, IL 60611. Stephen P. Wernet, PhD, is professor, Saint Louis University School of Social Work and Department of Public Policy. Correspondence regarding this article may be sent to the first author at phong@luc.edu or the address above.

Authors' note. An earlier version of this article was presented at the Annual Program Meeting (APM) of Council on Social Work Education (CSWE) in Anaheim, CA, on February 29, 2004.

Manuscript received: October 1, 2006

Revised: May 11, 2007

Accepted: May 31, 2007

\section{Endnotes}

${ }^{1}$ In bivariate analyses, each independent variable is examined individually in relation to working poverty. Statistically significant bivariate relationships justify including these variables in multivariate analyses. Further examination of these variables is conducted using multivariate models while controlling for the effects of other variables.

${ }^{2}$ According to Morrow-Howell \& Proctor (1992), the use of OLS with a binary-dependent variable is technically incorrect because several assumptions are violated. Binary-dependent variables are not normally distributed, the dependent variable and independent variables do not have a continuous linear relationship, and the error terms are not independent or homoscedastic. In this respect, an appropriate statistical procedure for modeling a dichotomous dependent variable is logistic regression. A series of these models were tested to examine the extent to which adding a set of variables in a sequence increases the likelihood of an individual being working poor.

${ }^{3}$ The likelihood ratio compares the likelihood function for the full model (unconstrained model) — one with the set of variables included in the model - to the likelihood function in a model without these variables (nested or constrained model). Significant test results indicate that the set of variables make a meaningful contribution to the model.

${ }^{4}$ Interpretation of the logistic regression results is made by examining the odds ratios. By exponentiating the parameter estimate (a)—noted as the odds ratio (ea) - the magnitude of the effects is observed. 